\title{
Recollections of a Country School Teacher
}

Anna Johnson

The one-room country school faded away for lack of students and because reorganization of school districts absorbed the remaining students into larger, consolidated systems. Anna Johnson believes that the smaller schools were far superior to the larger units. She would not want to go back to the old country school as it originally was, but furnished with proper supplies and equipment, as in its later years, the country school offered much that the conglomerates cannot. According to Mrs. Johnson, it is true the children of today are exposed to more educational units, but often also to larger classes. The latter circumstance, Mrs. Johnson believes, does not make for more efficient teachers. She taught in rural schools for twenty-two years, and laments that now "the one-room country school is gone. I feel sorry for the children of today who cannot enjoy many of the experiences of the generations before them. I am sure that the rural school played a very important part in the education of our people and the history of America."

MY GRANDPARENTS EMIGRATED from Chaslava, Bohemia in Austria about 1870 and took out a Homestead near Abie in Butler County, Nebraska to become farmers. My mother, who was fourth in a family of six children, received no education because there was no school within walking distance and there was no means of getting her there. Five years later a school was erected closer, but by that time she was too old and felt embarrassed to enter with other five-year-olds. So she vowed that if she

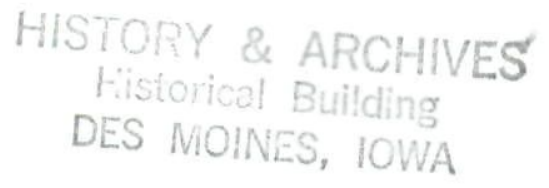


ever had any children they would receive that which she had been denied.

My father, on the other hand, was much older when he came to the United States from Sloupnic, Bohemia about 1888, so he had received an education equivalent to our eighth grade of today besides an apprenticeship in the shoe trade which he followed in Pocahontas, Iowa. He was one of the first settlers in the town, which celebrated its Centennial in 1970.

Six children were born to my parents, three boys and three girls. We all received a high school education thanks to the determination and sacrifice of those loving parents.

I had always said that I would never be a teacher, however I was "railroaded" into it by my father and the county superintendent of schools who was a very close friend of his. A contract was offered me to teach in a one-room rural school and my father insisted that I accept it, which I did.

My reasons for not wanting to teach were mainly based on certain actions of some of my teachers during my school years. I felt that they showed partiality in the treatment of some of my classmates whom I felt had been discriminated against because of their home life. Because my folks and others were foreigners and did not entertain the teachers as did the parents of some, good grades were lavished on those who had not always earned them. I honestly have to say that I got all that I had deserved, but I felt sorry for those who had not-so my feeling about teaching, at first, was not positive.

In the middle of my senior year in high school, January 1925, I took and passed a Rural Teacher's Examination which was a requirement for getting a teacher's certificate. Then I had to spend twelve weeks in summer school where I was supposed to prepare myself for the big task ahead of me. I took courses in Rural School Methods and Rural School Management, neither of which did anything to prepare me for the position facing me that fall, but I did receive a Second Grade County Certificate which entitled me to the above position.

Before retiring from the teaching profession in 1967, I had taught thirty-seven years, twenty-two of those years were spent in the rural schools of the county. The remaining fifteen years were spent teaching kindergarten and special reading.

Much has been said and written about the inferiority of the 
one-room rural school, but my past experiences in them make me take issue with this stand; I feel that they were superior to the village, town, or even the city school.

It is claimed by some that the rural children were cheated because they attended such small schools, were unable to share in sports, music, big school activities, and contact with classmates of their own age. On the contrary, I have always felt that they had many advantages over their city friends or cousins. True, they often did not have a classmate to challenge them, but they received a great deal of individual help during class sessions because they were alone or in a small group. They really had to learn to study on their own, and developed a sense of self-reliance. Once they returned to their seats, students had to depend on themselves.

The younger ones gained so much because they tried to keep up with the older ones and it was surprising what they could accomplish on their own when necessary. They learned much from just listening to the other classes when their own work was completed. I firmly believe that they often received a wealth of knowledge that no city school could ever have given them.

Students coming to my school from other school districts were sometimes so far behind, and did not know how to study or concentrate in the country school. This was due to the larger classes they had been in and because they received little or no individual help. Many teachers from town schools told us that our pupils were far in advance of their classes, and found it boring to repeat the work when they came to town.

The superiority of the one-room school can be best illustrated by a description of the physical make-up and the activities of the rural school I taught in Iowa beginning in 1925.

The early schools varied in style and architecture, but most of them had an entry or hall, a fuel room where the coal and cobs were kept, and one large classroom which was heated with an old fashioned pot-bellied stove (similar to the ones used in the original country schools), and located in the back of the room. On cold days those sitting close to the stove nearly roasted, while the rest were chilled to the bone, especially when the winds blew and whistled through the many cracks. Snow sifted in and settled on the window sills and on the floor where it did not even melt. On 
extremely cold days we all sat huddled around the stove with our wraps on.

In the front of the room was a platform where the teacher's desk was situated so that she could easily watch all of her charges. Next to her desk was the recitation seat for the classes she held. Also in the front was the main blackboard which usually was just painted board. In some of the schools there was blackboard all the way around the room including the back. A few schools had slate, but not very many. Above the boards were the maps, some so old that they dated back to pre-war days of 1914. In several of my schools I had a globe suspended from the ceiling by a rope and pulley which enabled me to lower it when in need and push it out of the way when I was finished with it. A storage closet was also found up in front for the supplies, library books, and for summer storage.

The scarred desks, many having been used by parents of the students, were arranged in two rows, the smaller to the front and the larger ones toward the back of the room. These desks were bolted to the floor so that they could not be moved. The back of one became the front of the next and so on down the line. Each desk contained an inkwell which could be a God-send as well as a big nuisance. If a bottle was used, it often upset or fell off the desk spilling ink all over the floor, the desk, and the student. Then again many a braid of hair ended in the inkwell, usually due to slight maneuvers of the one behind the victim.

The desks were arranged in such a way that there was one big center aisle and one on each side of the desks next to the window. This enabled me to walk freely around the room and watch the study habits of the students and to check on any mischief among those who usually sat together in what we called "doubles." The center aisle often became a play area during the noon hour or recess.

In the back of the room was a sand table for the little ones to play in. It was also used to set up science, history, or geography projects such as an Indian or Eskimo village or the plat of a community. There was also another table for library books in use, which was often called the "Work Done" table because it held many things of interest for those who had completed their regular assignments and had free time. Here I kept such things as puz- 


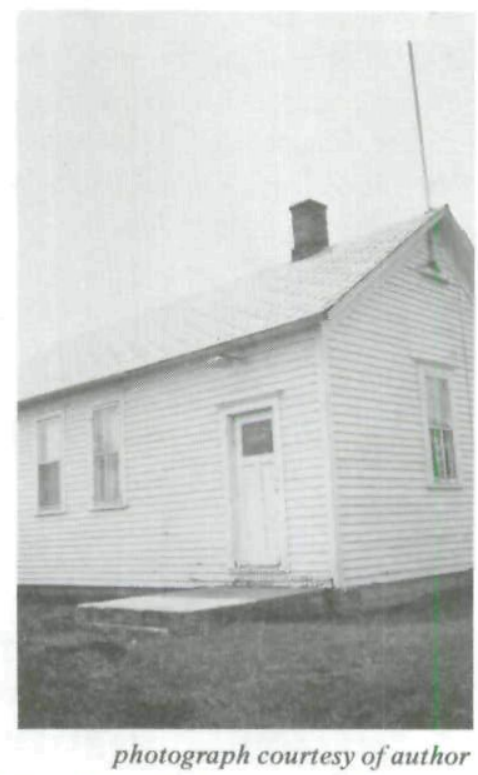

The first building Mrs. Johnson taught in is now used as a voting center.

zles, games, clay, art material, writing paper, and magazines.

The entry or hall held a table for the water cooler and the wash basin. There were hooks for the drinking cups above the table. On Monday each child brought his own cup and towel and then on Friday he took them home to be washed. If a cup was forgotten a paper cup was made and the kleenex box on my desk provided the towel. The wraps hung on hooks with the boots and lunch pails on the floor. During cold weather all of this had to be moved into the already over crowded classroom. Even then the lunches froze and ice formed on the water in the cooler.

There was no electrical lighting, only an oil lamp in some schools. The classroom had three big windows on each side with or without screens or storm windows. Both my students and I suffered much from flies, mosquitoes, and other insects during warm weather. Lunch time was almost more than we could take on some days and I could never understand or figure out why there was a screen door and yet no screens on the windows.

Only a few schools had their own wells, so water had to be carried by the older students from the nearest farm home which was 
often a half mile away. It was time consuming because most of the time the pail came back half full and another trip had to be made in order to have enough water for drinking and washing up. Sometimes an extra trip was made during the noon hour if the weather permitted or the day was extra warm. When the weather was bad a very compassionate director might bring us a five gallon cream can of water for which we all were very thankful.

Oh, I must not forget the outdoor plumbing with its crescentshaped window and last season's catalogue. Many a student did not return to the classroom on time because he was too busy looking through the "wishing book" to remember that he had more important work to do. Later the catalogue was replaced with regular tissue which gave me another problem. Each evening the rolls had to be brought in or the next morning I would find them gone or wrapped about the tree branches. Also I had to watch that it was not wasted; each school was given just enough to last the year, then back to the catalogue! I was also expected to check daily on the condition or cleanliness of the facility and see that no drawing had been donated during the day.

There were nine country schools in each district and each school was governed by a board consisting of a president, secretary, and treasurer, and one director. These board members, as a whole, hired and fired the teachers, decided on the wages to be paid and the supplies to be furnished for the school year such as fuel, and any supplies for the teacher (if they were alloted, which so often they were not). To keep the tax levies as low as possible the wages and supplies were also low. The director then was held responsible to see that all the fuel such as the coal, cobs, oil and repairs were taken care of before the school opened in the fall. He also had to see that the yard was mowed and building completely cleaned.

The walls were either washed or repainted. If the latter was done, the paint was a serviceable color but very drab. The building was cleaned again during the short Christmas vacation, but that too depended on how the director's wife felt because she was the one who had to do it. When it was done, it was appreciated by us; the floor got pretty dirty and dusty with so much traffic in all kinds of weather.

Such was the building which became my first school. When school started that fall, an eighteen-year-old teacher, very scared 
and nervous, having never been in or near a one-room country school before, faced six pupils and as many grades. One of these pupils was a first grader; in those days there was no pre-school or kindergarten in the country school. When I think of that day I still feel the butterflies in my stomach! And I still shudder when I think of that year-there just is no doubt in my mind but what the teacher learned more than her students, yet they must have gained something because most of them reached higher goals. If they learned anything, the credit must be given to the teacher who preceded me. She left an excellent class schedule which, with a few modifications, I was able to follow.

Of the first three years of teaching probably the most gratifying and successful was the third year, in 1928. By that time I was sure of myself and knew that I had gained much and also knew in my own heart that teaching was the career I wished to pursue. That year I was a member of a rural teacher's team that won the coveted prize during a May Day Celebration in Pocahontas. It was the custom for the whole county to take part in what was known as May Day at the end of the year. All schools, both city and country, took part in a big parade through the main part of town with all the children, bands, and floats from each town school and each rural district. The parade ended in the baseball field where various folk dances and the traditional May Pole Dances were conducted by the schools. This was followed by a picnic dinner and an afternoon of games. The day was finished when the judges announced the winning float for the year.

We teachers of Grant Township worked like beavers and put in many hours of labor after school, on Saturday, and even our evenings in building our float. We were proud of our labor but felt that we just did not have much chance in competition with the town schools. So imagine our joy when it was announced that Grant Township had unanimously been chosen winners with their float of "The Spirit Of Grant" commemorating Lindbergh's famous flight across the Atlantic in May of 1927. We were as elated as any of our students. The prize was $\$ 25$ which, after all expenses were deducted, we used to treat all those who so kindly and graciously helped us with the big project to ice cream and cake.

The duties of a rural teacher were many-faceted. I not only taught, but was also an administrator, mother, doctor, nurse, judge and jury, artist, cook, librarian, custodian or janitor, car- 
penter or fixer, advisor, psychologist, disciplinarian, and humanitarian. I might say that I was a "Jack of all trades and a master of some." In this rural community I was very close to the children and all the parents and many others in the area. Their problems often became my problems, which sometimes made my task even harder.

The average attendance in most schools at one time was about ten or twelve, however there were some schools where the enrollment was over twenty. My largest group was nineteen and consisted of nine grades. This was because one of my students came from another school district and did not fit into any of my grades so had to be taken care of on a separate basis. This perhaps was my first experience in special education or individual training. And perhaps it was the first of its kind in the county; I knew of no other case like it. I had had five years of experience behind me at that time or I am sure that I could not have coped with the situation.

The smallest school I taught consisted of two pupils. This occurred because on the first of February of that year a family moved out of the district taking seven of my pupils. The last four months were not only boring for the two students and me, but also a challenge in teaching because I had to be on my toes to keep them busy and interested. To make matters worse and even harder, they both were in the same grade, both eighth graders. In those days before a student could graduate from that grade he had to take county examinations administered by the county superintendent of schools. Much time was used in reviewing for those tests or examinations. But the noon hour and recess kept me busy thinking of something interesting to do for three people. That was one year I am sure that not only the children but their teacher were glad to see the last day arrive.

The school day for me, as well as for all other rural teachers, was long. It started early, often as early as 7:30 A.M., so that I could prepare for the day before the pupils arrived. If the weather was cold, I had to get the fire going in the stove and carry out the ashes from the day before. If one was expert enough in banking the fire the evening before, she found her building warm and all she had to do was stir up the coals and add fresh fuel. Placing the ashes on the coals at the right time and in the right way was not easy. Many a morning I arrived at school cold, only to find that I 
had no heat and a stove full of coal which had to be removed before a new fire was started. After installation of an oil burner with piped-in fuel, I found things a little easier. Yet I was firing my stove as late as the 40 s. Some teachers were able to hire older students to do this work, but I was never that fortunate!

The actual school session was from 9:00 A.M. to 4:00 P.M., with a fifteen-minute recess both morning and afternoon and a one-hour noon in the spring and the fall. In winter the noon hour was shortened to half an hour for two reasons. One, it got dark early and without proper lighting it was hard to conduct classes. The second reason was because most of the time the children could not go out of doors due to the cold or stormy weather and thus became very restless and hard to control. These long hours were extremely hard on the little first and second graders due to their short interest span and lack of study knowledge.

One of my most unusual experiences of those teaching days was because of these youngsters. If the weather permitted, I often let these younger ones out to play the last half hour of the day. They were instructed to stay within sight of my window so that I could keep an eye on their activities. But one very hectic day they disappeared from my vision and as I was in the middle of a very important arithmetic project I could not go out to check on them. The first free moment I had, I dashed out and to my horror found them trying to put sand in my car gas tank. Questioning them I found out that they had also put some water into the tank. Needless to say, that was the last free play for that group.

My problems were not over for the day. When I got ready to go home my car started immediately but soon began to sputter and spit and I limped into town on what I think were two cylinders. I reached a gas station just as the car stopped. Upon explaining the situation to the mechanic, he immediately began to work on my car. The gas tank had to be removed and the fuel line checked. Due to the odd and inaccessible location of the opening to the tank, luckily for me, they had not been able to get much in except for a few pebbles and a little water which had caused all my trouble.

$$
\text { \# \# }
$$

With dismissal of the students the day did not end for me, often it lasted until late into the night. I had my janitor work to do- 
such as sweep the floor, empty the waste basket and burn the papers, clean the blackboard and erasers, empty the water cooler, and bank the fire (always with a prayer that it would hold). If I were lucky enough, some of my older students would help me with the janitor work. There were no workbooks and I had to prepare work sheets, get any tests needed ready, and see that I had ample seat work for the small children. Then there was the correction of that day's accumulated work - the day's schedule did not leave me time to correct any of it during the day. I was supervisor from the moment the first child arrived and until the last one left. I always felt that if a paper was worth doing, it was worth correcting and also worth recorrecting if the child was to gain anything from that paper even though it meant more work for me. I took work home because it got dark too soon for me to do much after my janitor work was finished. When electricity was installed it helped some with the home work but did not cut down on the work load.

Probably the last two chores that I had to do before leaving were to check the fire and set mouse traps in my desk drawers because with cold weather, the field mice moved in. I do not know which I dreaded more, the cold stove or opening the drawer to check to see if I had caught any mice. Some days it was both a cold stove and several mice to remove from traps. The poor hungry things did not even need bait, there were always crumbs and paste even if they had to climb the walls to get at the pictures.

Besides my teaching material, I had to have two very important kits available. One was the first aid kit containing everything to take care of cuts, bruises, bites, scratches, burns and bumps. No telephone was available so in an emergency one of the older children had to run to the nearest home for help hoping that someone was there. My need for this help was very urgent one day when one of the little boys got caught under the teeter-totter and broke his leg. Luck was with me and help soon arrived.

The other kit was the "fix box" which held everything from screwdrivers, hammers, pliers, saws, nails, screws, pins of all kinds and sizes, needles and thread, buttons, scissors, patches, glue, oil can, paint brushes, two mouse traps. Oh, yes, many a rip was mended, button replaced, desk put together when it fell apart, hinges oiled to get rid of the squeaks, and my desk drawers pried open when they swelled shut.

I have laughed more than once over a particular incident of 


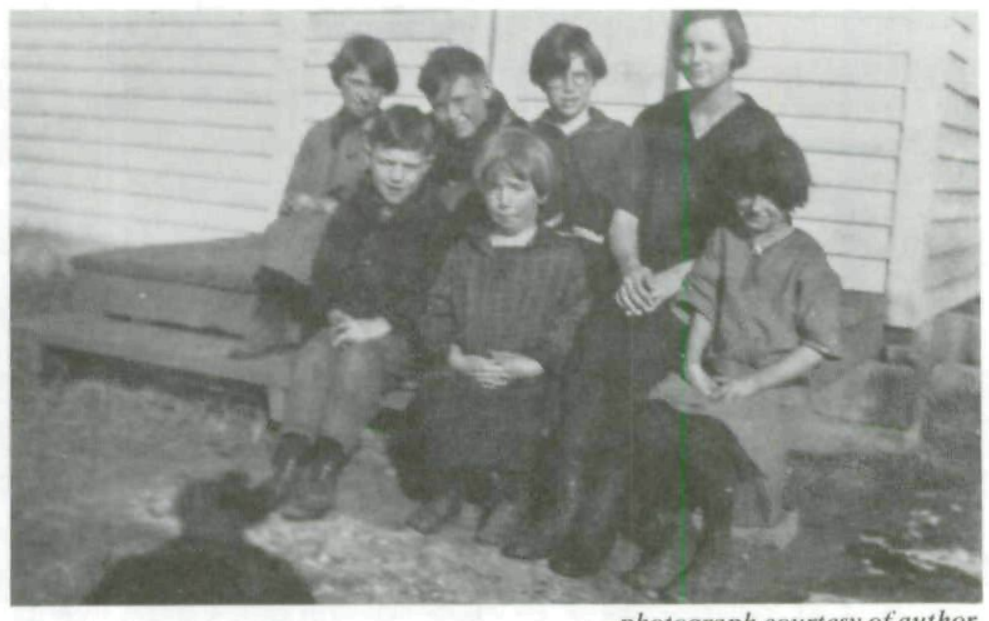

photograph courtesy of author

Mrs. Johnson with her first class in 1925.

ripped clothing. The students were forbidden to climb the trees on the school grounds, but whenever they got a chance they took it. One noon when I rang the bell and counted noses a fourth grade boy was missing. When I inquired about him all I got was giggles. Finally one of the boys told me that he fell out of a tree and could not come in. My heart sank to the bottom of my toes and I madly rushed out expecting the worst. He was sitting behind the school house with the seat of his pants completely ripped out. This was soon remedied; he removed his trousers and gave them to me while he remained in the entry. I sewed the patch back in and he then returned to the classroom. No punishment was meted out that day as I felt that he had had enough for one day. The outcome was that there was no more tree climbing in that school.

The "fix box" was used in still another way much to my anger as you will see from the next little episode. One of the hardest days I ever had in those twenty-two years of teaching was one cold, fall day. On the way to school I had a flat tire on the car and that delayed my arrival. When I got there, I found myself not locked out but barred out. Someone had boarded the door from the inside. All the windows but one were locked from the inside and that one was nailed shut. I backed the car up to the building and with a tire tool and a screw driver climbed up on the car and 
began prying out the nails. By that time all of my students had arrived and were watching my maneuvers. Once the nails were out, I was able to open the window, climb in through it, and pry the bar loose which had been tightly nailed over the door.

By that time I was really hot under the collar, not just from working but at the thought of what had been done and by whom - two of my over zealous boys! The irony of it was that the hammer and nails came from my "fix box" and the bar was from our supply of lumber to be used in art projects. I had the fire to build, check my desk for mice, and the water had to be brought and it was way past school time. The building was too cold to start any classes which delayed things even more. Those two slipped away with the water pail and were soon back with a full pail of water. Not a thing went right from start to finish that day. I gave the two boys a very cold shoulder, except in class, but believe me their assignments were more than doubled that day. I had no pity for them and they knew it without my saying one word.

After school the two boys stayed of their own free will and told me how sorry they were and promised never, never to do anything like that again. The climax of the whole thing came when I began to think about the picture I must have made when I was on the car prying nails loose and then crawling in through the window. I sat down on the porch step and laughed harder than I had for a long time. At first they looked at me as if they thought I had lost my mind, and then began to laugh as hard as I. That afternoon I gained two very good friends who just could not do enough for me the rest of the year.

With the two kits mentioned I also had two "must" items in my school. They were an ample supply of kleenex and clean rags. The latter usually were pieces of old sheets. Both of these came in handy for runny noses, nose bleeds, mopping up spills, washing off desks and the blackboard, as paint rags, and with a little oil as good dust cloths. It was surprising how often they were needed and used each day.

No matter how many grades, nor how many classes, nor how many students, nor how much work was to be done, my day always started the same way. The bell was rung five minutes to nine and five minutes to one o'clock which gave the children time to go to the rest room and sharpen their pencils. All had to be in their seats by nine o'clock, anyone coming in after that went into the 
records as "late." Then the day began with a short prayer and the pledge to the flag which held a prominent position in the front of the room above the blackboard. Both morning and afternoon a ten- or fifteen-minute reading period was held when I read to the group. It gave them a chance to relax after hard play and settle down for the work ahead of us. It also gave them an appreciation for good books. The book chosen had to be one of interest to all ages so the first grader as well as the eighth grader could enjoy it. Sometimes I read books brought by the pupils, but if not of interest to all, it was read to the level for which it was meant. Never did I refuse to read any book brought by the children even though I might not care for it.

In order to help the children enjoy poetry, something I could not do for a long time because my teachërs had made me memorize poetry as a punishment, I did not require that they memorize any, but I did read a lot of poetry. My Anthology of Literature was my favorite book and used often. I also encouraged the writing of original poetry and all were posted on the bulletin board whether good or bad. It was surprising the excellency of some that were composed by even the youngest. They loved it.

Perhaps my main reason for free reading of good books and poetry stemmed from the fact that our library was most deplorable. It held books which had been donated to the school, so old, so complex that not even I cared to look at them. I supplemented it with books from my local library in order to expose these children to good books. Later the rural teachers formed a teacher's organization and their dues were used to buy books. This library was kept in the superintendent's office and all books of all levels became available to us, for which we were glad. Even later the state sent funds which could be used to purchase new library books, and I was given the chance to choose the ones I wished, which did much to build my school library.

Reading, writing, and arithmetic were not the only subjects taught by rural teachers. Of course they led in importance and I decry the lack of teaching real penmanship in our schools of today. The Palmer Method was used and a special time was given for this purpose. During writing period should aryone walk into my classroom, he would hear me counting, depending on the circles, ovals, or letter on which the children were practicing; it was all done with a form of rhythm to encourage slow, fluent writing. 
These practice sheets were kept so that each child could evaluate his own work at the end of the year. Not all became good writers, but without practice there would indeed have been many more poor writers. I was not taught penmanship when I went to school and my writing is anything but legible at times, yet I feel that those practice sessions helped me, too.

Then there were geography, history, science, hygiene, spelling, art, language, agriculture, civics, Iowa history, current events, and physical education to be learned. The latter I found quite unnecessary in the country school where farm children got more exercise and used more muscles in their bodies each day than their counterparts in the city, but required it was, so I had to include it in my weekly schedule even though it was already overloaded.

A class period could be anywhere from ten to twenty minutes long depending on how many grades I had and the grade level. The first and second graders had so few classes that they were given longer periods. I felt the older ones were able to manage on a shorter time. Then my schedule was flexible enough that if more time was needed in one class it could be taken from another or the other could be missed for the time being. Wherever it was possible the classes were combined such as art, science, hygiene, and agriculture. Each grade was working on material at its own level, yet was able to contribute to a good discussion. And as mentioned before the sand table helped in class participation. During a spelling period as many as three grades could be writing their words because I would pronounce a word for each in turn thus saving precious time. Arithmetic class might consist of a group working at the board under supervision, another group on an assignment at their seats, while a third would be having new methods presented to them, or there could just be a drill on the basic combinations. They simply had to be learned as there was no time for the teacher or the pupil to wait while they counted on their fingers, made marks, or experimented with various methods to get the answer. Classes also were alternated: geography on Monday and Wednesday and history on Tuesday and Thursday. Agriculture, art, and hygiene were on Friday. Civics and Iowa history replaced geography in the eighth grade, one each semester. But reading, arithmetic and spelling were held five days a week. I might add that sometimes the older students helped the younger 
ones with their spelling, word drill, or the combinations. It was just "One Big Happy Family" which chipped in to get the necessary work done.

As I mentioned before, most of the time I was expected to buy most of my supplies. I made my own paste, and my own hectograph, which consisted of a gelatin base and was poured into a cake pan. With special ink one could make as many copies as needed, but with each use, the ink had to be washed off before it could be used again. Carbon paper also enabled me to make extra copies. Often I furnished my own material and made curtains for the windows to cheer up the room following a drab paint job, or the lack of it. And in several schools I furnished my own bulletin boards which I needed and used so often.

Consiciering the low wages received at that time, expenditures of this kind often resulted in a nearly empty pocket-book at the end of the month. When I read about our teacher strikes of today demanding more pay, less hours, extra help, playground supervision, and fringe benefits, I cannot help but give a big sigh for those rural teachers of the past.

My first year of teaching netted me the large sum of $\$ 50$ a month. Out of that I had to pay $\$ 20$ for room and board, $\$ 25$ to pay back a loan for my summer school session, and buy my supplies: paper, paste, hectograph material, crayons, and sometimes even the chalk I had to use. Needless to say, experience was about all I was gaining! The second year I received a First Grade County Certificate due to the year's experience and my salary was increased to $\$ 55$ a month. The third year it went up to $\$ 60$ and remained at that level for the next nine years.

During the Depression I taught nine months and was paid for eight of them. I was given a chance of quitting at the end of the eighth month, but my conscience would not let me do it. In the twenty-two years of teaching in the rural schools my highest wage rose to $\$ 250$ per month, with a total of $\$ 2,250$ for the year. This was pretty close to the average wage for most rural school teachers, some getting more and others less, depending on their school boards. Figures show that there was a little over $\$ 9$ a month increase during those many teaching years.

Of course with expenses kept down the playground suffered, too. Some of the early schools had no playground equipment so again the teacher had to improvise to keep the children busy dur- 
ing that long noon hour and the recesses. Games like Run, Sheep, Run, Red Rover, Andy-I-Over, Pump-Pump-Pull-Away, Two or Three Deep, Black and White, Drop the Handkerchief, Seven Leagues, Hide-and-Seek, Blindman's Bluff, King-on-theMountain, Statue, Touch-Tag, Keep-Away, Fox-and-Goose, and baseball did much to shorten that noon hour.

During inclement weather and the winter months, indoor games were played in the classroom: Squares, Hang-Man, Catand-Mouse, Tick-Tack-Toe, Fruit Basket Upset, Magical Chairs, and Going to Grandmother's. Many readers will recall all of these and many more, but to some, and many of our children today they will mean absolutely nothing.

$$
\text { \# \# }
$$

The rural teachers were faced with many problems which they were not prepared to handle due to the lack of training. A certificate from a Normal Training High School, or one like I had received after twelve weeks of summer school, did not ease the extra load. I was faced with teaching a near-blind boy, one with a cleft palate which had not been corrected, a cerebral palsied child, a child crippled from polio, slow learners as well as the mentally retarded. As was the case until the last fifteen or twenty years, many of these received the short end of the deal because of the time factor and the teacher not being trained to deal with them. In my own heart I feel that I helped some a lot, a few just a little bit, but each received some of my time and all the knowledge that I had. If a child was in a class by himself, I was able to give him a lot more time than I could if there were several others at his level. The normal children could not be deprived of their share of help, of course.

A teacher has to be a disciplinarian, which is often very hard. My belief then and still is today that children must learn to discipline themselves. On my first day of school I made no rules; I told the students that it was up to them to conduct themselves properly, but it was understood that if necessary I would impose rules of conduct. They chose their own judge and they were the jury. My problem then was to see that the punishment meted out was not too excessive, as it often could be. They learned to respect and obey any rules that they set up themselves, which made my task easier. Yet, as in all cases, problems arose which I alone had to 
deal with, and sometimes even had to call on the parents to help participate. As a rule problems with the younger ones were not great, but those with the older boys often were not easy. They had so often heard of the pranks that father or grandfather had pulled, and of course they tried to imitate or see if they could be even better. Then of course they all had to try out the "New Teacher" until they knew where they stood with her and how far they could or dared to go.

In one school I had two large eighth grade boys, and were they trouble makers! I never knew what to expect and my first thought each morning was, "Now what?" One day I smelled cigarette smoke and it did not take long to figure out from where it was coming. I said nothing, but watched closely as the boys were hiding the burning cigarettes in their desk after each puff and I was worried about the danger of fire. But on dismissal I asked the two boys to please stay after school and help me with a big problem. They were all grins and happy because I had not caught them smoking. When I explained my problem, and the danger that they had placed themselves and the rest of the school in, the two were crestfallen, and tears came to their eyes. I accepted their apologies with a promise that it would not happen again and that they would leave father's cigarettes alone. That ended that incident, but left me wondering what would be the next.

Another incident with one of these boys was much graver and by far more serious. He had received a rifle from his parents as a gift, but was told that he was not to take it off the place without their consent. He did, however, and I found out that he brought it to school each morning and hid it in the ditch across the road from the school. Every afternoon after dismissal he would shoot at the heels of those children going in his direction, making them run home. Once again I asked him to stay after school and help me, but this time he was suspicious. I again explained the situation to him, and told him that when he left home in the morning his folks were responsible for him until he reached school. Then I was responsible for him and all the rest of the children until they reached home. I wanted to know if he realized the danger he had put them in when he shot at their heels, pointing out that bullets could and often did ricochet. Had anything happened to them I would have been indirectly responsible along with him and his parents. His answer was that he did not mean any harm, was only 
teasing and was sorry for what he had done. We both agreed that he should get some kind of punishment and he left it up to me to decide what it should be. So we came to an agreement; he was to take the rifle home and explain to his parents what he had done. If he did not, then I would tell them and also the local authorities, which would not only get him into trouble but his parents as well. He kept his promise and the next morning his father came to thank me for ironing out a very difficult problem that could have been very serious. He lost the use of the rifle for a long time.

We teachers were called upon to do many things besides teaching and maintaining discipline. We often had to administer medication at given times during the day. Once I had a student that was diabetic. I had to be very sure that her medicine was given at the right time and the same time each day. In one school I had a second grade boy who had an eye that was starting to cross and had to be corrected. Beginning on Monday I covered the good eye with a special patch for five minutes each day for a week. The next week I increased the time to ten minutes, and each week the time increased until finally the good eye was completely covered all day. Thus the muscles of the weak eye gradually developed until the boy had normal vision. But it was my responsibility since he hated it so much. Had I forgotten, he would never have reminded me. That was the first thing I did each morning.

In case of any emergency it was I who had to make the decision as to what should be done, when, and how. One very cold, wintry day when all the roads were closed and the only means of transportation was walking, it started to snow and by mid-afternoon a blizzard raged outside the school house. I was very concerned as I knew that no one could possibly get to the school for their children. I dreaded the thought of spending the night in the building without lights or food. The children were beginning to get restless and I prayed for the strength and the courage to face what I knew was ahead of us. Suddenly the door burst open and there was my director. He informed me that he had called all the parents and was taking the children to his place. We quickly bundled each one, wrapping scarves over their faces to protect them as much as possible from the lashing wind and snow. $\mathrm{He}$ had a rope which he tied around his waist and we started out with him in the lead holding on to the youngest one who in turn held on to the rope. We sandwiched an older child between a younger 
one and demanded that they hold on to the rope and keep as close as possible to the one in front. I brought up the rear. Even though the distance was no farther than three long city blocks, the going was rough, what with the deep snow and poor visibility, and to me it seemed as if we would never reach our destination. When we reached the farm house, the parents were again called to let them know that we had made it safely. It was a crowded place, but we were happy, warm, and safe. I can never explain how much it meant to me to have such a great responsibility taken from my shoulders.

$$
\text { \# \# }
$$

We really were not cooks, but had to heat soup and beans, bake potatoes in the ashes and heat food which was brought to school after a hot lunch program was started. Often the meal was sent early in the morning and $I$ had to reheat or keep it warm. We each brought our own sandwiches and dishes, and one family each day was to see that a hot dish was furnished. Then I had to see that it was served and divided evenly. Some days we got nothing because mother forgot, or two meals were brought the same day, or it was brought just as we were about to start our classes. But these hot meals were really appreciated after eating a cold meal in a cold school for many years.

Of all the subjects taught I believe that science and art were appreciated the most by both the children and me. My windows in late winter were lined with jar after jar of various seeds. Some in clay, ashes, sand, and rich loam. Some were in the sun and others in the shade. Some got too much water, some a little and some none. They were rotated often so that the children could observe the effect of various experiments. The first thing each child did was to check his particular jar when he got to school and worried if the seeds were not growing or did not seem to be responding and was happy if the results were good. This project did much to help them understand the problems that their parents had with the crops they were growing.

On one occassion the children had a first-hand experience with a family of skunks. A mother and her family of six babies had taken residence under the school house. She had dug a hole under the porch for the entrance to her home. A little odor was sometimes noticed but not too bad. Not even the noise of the chil- 
dren seemed to bother her or upset her in anyway. One morning we saw the mother, and her six babies following Indian file, up the drive, walk to the porch, and enter her doorway. Our presence just three feet away from her did not in any way alarm her. The children learned that if they did not bother her, she would not harm them. At the end of the year she was smoked out, but it was something that just could not have been done before.

It wasn't all work and no play for rural teachers and students. We all looked forward to special days and holidays. Halloween and Valentine's Day meant parties and treats. But Christmas and the last day of school were the most looked-for days; not only did the school participate, but the whole community, including many friends and relatives.

Christmas meant a program which was held in the afternoon until electric lights were installed. Plays, poems, stories, pantomimes, and songs were presented. Sometimes the older children wrote their own plays, poems, or stories. The front of the classroom was curtained off by sheets or blankets for the stage and the hall was used as the dressing room. Many a noon hour and recess was spent practicing. Parts were recited, and props were constructed. The microphone with a radio setting and the call letters of XMAS was an item that the children enjoyed making for the Christmas program.

Following the program there was a gift exchange and treats for the children in addition to a bushel of apples which did not last long. Then best of all-a few days of vacation, but never very long.

The last day of school meant a huge pot-luck dinner with ice cream furnished by the teacher as her share of the dinner. I sever saw so much good food, so much fun, or such big crowds. Everyone in the school community came. Games of all sorts were played: baseball, catch, horseshoe, quoits, races, and contests of all kinds. Everyone took part in the final festivities of the year. Then three months of vacation for all, including me unless I went to summer school. But even if I did, it was a big change from the pace I had been keeping for nine months.

The job of the one-room rural teacher was a hard one, but also challenging and fun! I am sure that most of those who taught in the one-room school in the early days will agree with me on this. I am sure that I was far happier with all my work than the teachers 
of today with their higher wages (even though many are still underpaid), fringe benefits, modern equipment and strikes. Since I taught in town also I do know the difference between the two. I am sure that without the experience I gained in the country school I never could have done the job required of me in the town school. I had forty-two in kindergarten for just a half day and according to my contract was expected to teach reading to them. How much more my first graders in the rural school learned from me because my classes were small.

Many changes occurred in the country schools during my years of teaching. The old theory of "What was good enough for me is good enough for my children" was dropped and the parents began to want the best for their offspring. The old coal stove was replaced by an oil-burning stove and the fuel was piped in from outside. The building was wired for electricity after the REA was established and even a telephone was installed in some of the schools. Slate took the place of the painted blackboard. The old desks were replaced with new singles or the old ones were planed down to get rid of the carved or gouged spots and then refinished. The walls were painted with light cheerful paint which made it easier on the eyes. The old maps were removed and updated ones put in, and eventually I was even furnished with a set of reference books (which I had had before only when I furnished my own). Extra bulletin board so badly needed was installed where the old painted blackboards had been. And most of the supplies I needed and asked for were included in the budget.

All the buildings were maintained in better condition, repaired, and painted. Storm windows and screens were added. Playground equipment such as swings, slides, and teeter-totter were furnished along with a baseball, bat, and basketball with a hoop. In some schools even wells were drilled. All this did much to ease the load of the rural school teacher and made things more interesting for the children. Conditions have changed dramatically over the years. It took over twenty-two years to bring about most of these changes. 
Copyright of Annals of Iowa is the property of State of Iowa, by \& through the State Historical Society of Iowa and its content may not be copied or emailed to multiple sites or posted to a listserv without the copyright holder's express written permission. However, users may print, download, or email articles for individual use. 